\title{
Genetic Diversity Analysis in Black Gram (Vigna mungo L. Hepper)
}

\author{
Dondiba Kundagar*, N. Brajendra Singh, M. Samuel Jeberson, \\ Bireswar Sinha and N. Gopimohan Singh
}

Department of Genetics and Plant Breeding, College of Agriculture, CAU, Imphal - 795 004, India

*Corresponding author

\section{A B S T R A C T}

Keywords

Black gram,

Genetic variability, Heritability, GCA \& PCA, Genetic advance, Genetic diversity

\section{Article Info}

\section{Accepted:}

12 December 2020 Available Online: 10 January 2021
The present investigation was carried out with fifty blackgram genotypes to study the genetic diversity for 14 characters during Kharif, 2019. For all the characters analysis of variance presented significant differences. For all the characters the genotypic coefficient of variation (GCV) was smaller than the phenotypic coefficient of variation (PCV). Wholly the traits have shown high heritability but high heritability together with high genetic advance was revealed by number of secondary branches per plant, number of seeds per plant, number of pods per plant, plant height, biological yield per plant and number of clusters per plant indicating the substantial contribution of additive gene action. For 100 seed weight, number of primary branches per plant, harvest index, seed yield per plant, days to $50 \%$ flowering, pod length, number of seeds per pod, and days to maturity, which specify equal impact of additive and non-additive genetic action in the expression, high heritability with moderate to low genetic advancement was reported.

\section{Introduction}

Blackgram (Vigna mungo L. Hepper) is one of the most important pulse crops of India. Blackgram is popularly known as urdbean or Mash in India and is a grain legume domesticated from $V$. mungo var. silvestris. It is a self-pollinated crop with diploid chromosome number $2 n=22$. It contributes $12 \%$ of the total pulse production of the country. It is a rich source of protein (20.8 to 30.5 per cent) with total carbohydrates ranging from 56.5 to 63.7 per cent. It contains a wide variety of nutrients and is popular for its fermenting action and thus it is largely used in making fermented foods. Blackgram is cultivated as a sole crop and intercrop.

Vigna, a pantropical genus, comprises about 150 species, most of which are found in Asia 
and Africa. Only seven species of Vigna are cultivated as pulse crops, of which two are of African and five have Asiatic origin. The Vigna, species are adapted to a range of agroclimatic conditions and their growth on marginal lands without supplementing nitrogen is particularly an added advantage for subsistence agriculture. It is classified into two sub species.

a. Vigna mungo var. virdis: Plant type of this sub species mature late and seeds are small with greenish look.

b. Vigna mungo var. niger: Plant type of this group mature early with bigger and bold seeds of black colour.

Black gram is widely cultivated in the Indian subcontinent and to a lesser extent in Thailand, Australia, and other Asian and South Pacific countries (Poehlman, 1991). It is grown in an area of about 5.44 million hectares in India with production of 3.56 million tonnes and productivity of $653 \mathrm{~kg} / \mathrm{ha}$ (Anonymous, 2017-18). Production and productivity of black gram is highest in Maharashtra. In India, it is grown in Andhra Pradesh, Maharashtra, Orissa, Madhya Pradesh, Tamil Nadu, West Bengal and Uttar Pradesh.

Major constraints in achieving higher yield of this crop are lack of genetic variability, thermo sensitivity, absence of suitable ideotypes for different cropping systems, poor harvest index and susceptibility to pests and diseases. Research on this crop has lagged behind that of cereals and other legumes. Therefore, improvement of this crop is needed through utilization of available genetic diversity. The evaluation of genetic diversity and construction of linkage maps would promote the efficient use of genetic variations in the breeding program (Paterson et al., 1991).
Genetic diversity is an important factor and also a prerequisite in any hybridization programme. The accurate estimation of genetic diversity can be invaluable in the selection of diverse parental combinations to generate segregating progenies with maximum genetic variability. The study of genetic diversity can be particularly useful for precise identification of pureliness or cultivars with respect to plant varietal protection and germplasm maintenance by removing the duplicity and misidentity in the core accessions. Furthermore, monitoring the genetic variability within the gene pool of elite breeding material could make crop improvement more efficient by the directed accumulation of favoured alleles.

To accomplish this, crop improvement should aim at broadening the genetic base of the breeding stock. Success in crop improvement generally depends on magnitude of genetic variability and the extent to which the desirable characters are heritable. Hence, keeping the above facts in view, the present investigation entitled "Genetic Diversity Analysis in Black Gram (Vigna mungo L. Hepper)" is undertaken with the following objectives include to evaluate the per se performance of different black gram cultivars. To measure the genetic diversity among the available genotypes of black gram. And also to find out suitable parent for further genetic improvement of the black gram.

\section{Materials and Methods}

For the present study, fifty black gram genotypes were collected from IIPR, Kanpur (Table 1). The genotypes were laid in randomized block design (RBD) with three replications at Andro Research Farm, Central Agricultural University, Imphal during kharif 2019. The research farm is located at $24^{0} 46$ $\mathrm{N}$ and $94^{\circ} 03^{\prime} \mathrm{E}$. Each plot was sown in 10 rows of $4 \mathrm{~m}$ length with a spacing of $30 \mathrm{~cm} \mathrm{X}$ 
$20 \mathrm{~cm}$ between and within rows. All the other recommended package of practices was followed during the crop growth to raise good crop. The genotypes were harvested as and when pods matured. Five plants from each replication were randomly selected for recording observations on various characters such as days to $50 \%$ flowering, days to maturity, plant height, number of primary branches per plant, number of secondary branches per plant, number of pods per plant, pod length, number of clusters per plant, number of seeds per pod, number of seeds per plant, biological yield per plant, seed yield per plant, harvest index, 100 seeds weight. The data obtained were subjected to standard statistical procedures.

\section{Results and Discussion}

The findings of the present investigation have been interpreted and discussed in this chapter. The present study was carried out to study the genetic architecture and information on different growth, yield and its traits on 50 blackgram different genotypes of blackgram. Bright knowledge of genetic information with regard to extent of genetic variability for seed yield per plant and its components, helps in understanding the characters influencing the yield. Discussion pertaining to the result of the present study has been shown under the following genetic parameters PCV \& GCV, heritability and Genetic Advance.

The analysis of variance for the design of the experiment under study was calculated separately for each trait. The total variance was subdivided into components attributable to different sources and the results from analysis of variance have been presented in Table (2). The mean sum of squares based on ANOVA of 50 blackgram genotypes for 14 characters indicated the presence of high amount of variability among the genotypes. It was detected that estimated analysis of variance (Table 2) revealed that variance present in various genotypes for all the studied characters were highly significant.

The values of phenotypic coefficient of variation were higher than that of the genotypic coefficient of variation for all the character. Maximum PCV was (24.30) recorded for number of secondary branches followed by number of pods per plant (23.69), plant height (20.48), harvest index (19.91), number of clusters per plant (19.73), number of primary branches (17.57), seed yield per plant (16.79), biological yield per plant (16.09), number of seeds per plant (14.67), 100 seed weight (7.53), pod length (7.30), number of seeds per pod (7.21), days to maturity (5.17) and days to $50 \%$ flowering (4.69) (Table 4). Maximum GCV was (22.84) recorded for number of secondary branches followed by number of pods per plant (21.63), plant height (19.58), number of clusters per plant (18.31), harvest index (15.03), biological yield per plant(14.47), number of primary branches (13.95), number of seeds per plant (13.69), seed yield per plant (13.30), 100 seed weight (5.63), number of seeds per pod (4.67), pod length (4.02), days to maturity (1.94) and the lowest GCV was observed in days to $50 \%$ flowering (1.85) (Table 4). Phenotypic coefficient of variation was observed to be higher than the genotypic coefficient variation for all the traits under study. It indicates the influence of environment in the expression of traits.

Similar result was given by Konda et al., (2009), Ramya et al., (2014) in black gram. Characters viz., days to $50 \%$ flowering, pod length, number of seeds per pod, 100 seed weight and days to maturity showed low magnitude of GCV and PCV. Similar results were obtained by Konda et al., (2009). Number of primary branches per plant, number of seeds per plant, seed yield per plant and biological yield per plant showed 
moderate magnitude on GCV and PCV. Whereas, the maximum GCV and PCV recorded for number of secondary branches per plant, harvest index, number of pods per plant, number of clusters per plant and plant height. Thus, among the traits studied, these are the most variable one. Similar results were obtained by Reddy et al., (2011) in black gram. Some amount of variation present in between PCV and GCV for characters such as number of pods per plant, number of seeds per plant, number of branches per plant, seed yield per plant and harvest index which are probably due to higher influences of environmental factors on the expression of these traits.

Heritability (broad sense) estimates were high for all the traits under the study(Table 4). It was pictorially depicted in Figure 2. The heritability ranged from 17.30 to 95.63 . Among the fourteen characters studied, heritability of plant height showed the highest value (95.63), followed by number of secondary branches (94.02), number of seeds per plant (93.31), number of clusters per plant (92.81), number of pods per plant (91.30), biological yield per plant (89.92), number of primary branches (79.40), seed yield per plant (79.21), and harvest index (75.48), 100 seed weight(74.66), number of seeds per pod (64.82). The characters, pod length (55.05), days to $50 \%$ flowering (39.51) and days to maturity (37.63) were shown moderate heritability. Genetic advance (GA) was found highest for number of pods per plant (7.07) followed by number of secondary branches (9.55) and number of pods per plant (9.15). Whereas, high genetic advance over its mean was recorded for number of primary branches (149.06) followed by seed yield per plant (141.96), number of secondary branches (93.60) and 100 seed weight (92.99). The estimates of genetic advance expressed as percentage of mean were presented in Table 4 and pictorially depicted in Figure 3. Moderate genetic advance over its mean was recorded for the characters like, number of clusters per plant (70.77), pod length (59.87), number of seeds per pod (56.02) and biological yield per plant (40.82). For number of pods per plant (35.48), harvest index (35.35), plant height (22.28), number of seeds per plant (6.88), days to $50 \%$ flowering (3.67) and days to maturity (2.20) very low value was recorded. High heritability coupled with high to moderate genetic advance as per mean was indicating that predominance of additive gene action. High heritability coupled with low GA indicating that the presence of non-additive gene action.

The proportion of genetic variability which is transmitted from parents to progeny is explained by heritability. Burton (1952) suggested that the genetic variation along with the heritability will give better idea about expected efficiency of selection. Heritability estimates along with genetic advance are more helpful in predicting the gain under selection (Johnson et al., 1955). In the present study, of all the characters under study number of secondary branches per plant, number of seeds per plant, number of pods per plant, plant height, biological yield per plant and number of clusters per plant have shown high heritability, Similar result was observed by Gupta et al., (2006), Makeen et al., (2007), Reddy et al., (2011) in black gram. Characters like 100 seed weight, number of primary branches per plant, harvest index, seed yield per plant have shown moderate level of heritability, which have shown high heritability for the following findings viz., Venkatesan et al., (2005), Konda et al., (2009) in black gram and characters like days to $50 \%$ flowering, pod length, number of seeds per pod, and days to maturity have shown low heritability. The high heritability coupled with high genetic advance was recorded for number of secondary branches per plant, number of 
seeds per plant, number of pods per plant, plant height, biological yield per plant and number of clusters per plant, indicating the substantial contribution of additive gene action (Panse,1957). On these traits direct selection may improve yield. Similar result was found by Gupta et al., (2006), Neelavathi and Govindarasu (2010) in black gram. High heritability with moderate to low genetic advance was recorded for 100 seed weight, number of primary branches per plant, harvest index, seed yield per plant, days to 50\% flowering, pod length, number of seeds per pod, and days to maturity which specify equal influence of additive and non-additive genetic action in the expression.

Table.3.2 Experimental materials

\begin{tabular}{|c|c|c|c|}
\hline Sl. No. & Genotypes & Pedigrees & Sources \\
\hline 1 & ABFBG 04 & LBG $625 \times$ PU 31 & $\begin{array}{l}\text { Agri. Biotech. Foundation, } \\
\text { Hyderabad }\end{array}$ \\
\hline 2 & ACM 16-017 & Mutant of MDU $1(500 \mathrm{GY})$ & ARS, Aduthurai \\
\hline 3 & AKU 1608 & TAU $1 \times$ PU 31 & PDKV, Akola \\
\hline 4 & AKU 18-1 & TAU 1 x IPU 2-43 & PDKV, Akola \\
\hline 5 & BDU-12 & TAU 1 x KU 96-3 & Bidar, Raichur \\
\hline 6 & DBGV 16 & TAU $1 \times$ DU 1 & UAS, Dharwad \\
\hline 7 & DBGV 19 & DBGV $5 \times$ PU 31 & UAS, Dharwad \\
\hline 8 & DKU 90 & KU 53 x KU 154 & CSK HPKV, Palampur \\
\hline 9 & GJU 1509 & COBG 593 x TPU 4 & SDAU, S. K. Nagar \\
\hline 10 & IPU $12-5$ & UH 85-5 x Vigna sylvestris & IIPR, Kanpur \\
\hline 11 & IPU 17-1 & PGRU 95027 x DPU 88-31 & IIPR, Kanpur \\
\hline 12 & IPU 18-1 & PGRU 95027 x DPU 88-31 & IIPR, Kanpur \\
\hline 13 & IU 04-3 & AKU 15 x KU 96-3 & IGKVV, Raipur \\
\hline 14 & KPU 13-241 & KPU 1012 x M 1008 & ARS, Kota \\
\hline 15 & KPU 514-75 & KPU $11-39$ x KPU 406 & ARS, Kota \\
\hline 16 & KPU 520-69 & RBU 1012 x KPU 96-3 & ARS, Kota \\
\hline 17 & KPU 52-87 & RBU 1012 x KPU 96-3 & ARS, Kota \\
\hline 18 & KU 17-08 & Azad U 1 x Bulandshahar Local & CSAU, Kanpur \\
\hline 19 & KU I7-04 & Shekhar 3 x KU 7701 & CSAU, Kanpur \\
\hline 20 & KUG 818 & KUG 540 x Pant U 19 & PAU, Ludhiana \\
\hline 21 & KUG 883 & MASH $338 \times$ MASH 479 & PAU, Ludhiana \\
\hline 22 & KUG 898 & KUG 502 x KUG 540 & PAU, Ludhiana \\
\hline 23 & LBG 904 & LBG $645 \times$ TU 94-2 & ARS, Lam \\
\hline 24 & LBG 932 & $\begin{array}{l}\text { (KU 96-3 x LBG 20) x (LBG } 752 \\
\text { x TU 2) }\end{array}$ & RARS, Lam \\
\hline 25 & MBG 1069 & MBG 211 x IPU 98-1 & ARS, Madhira \\
\hline 26 & MBG 1070 & MBG 211 x IPU 98-1 & ARS, Madhira \\
\hline 27 & MU 52 & Vishwas x BDU 1 & MSSC Ltd. AKola \\
\hline 28 & NDUK 17-05 & NDU - 2 xPant U 31 & NDUAT, Faizabad \\
\hline 29 & OBG 103 & PDU $1 \times 19$ & OUAT, Bhabaneswar \\
\hline 30 & OBG 41 & PU 19 x KU 96-3 & OUAT, Bhabaneswar \\
\hline
\end{tabular}




\begin{tabular}{|r|l|l|l|}
\hline 31 & $\begin{array}{l}\text { Pant U 31 } \\
\text { (Ch.) }\end{array}$ & UPU 97-10 x DPU 88-31 & GBPAUT, Pantnagar \\
\hline $\mathbf{3 2}$ & PU 1501 & PU 40 X Mash 1008 & GBPAUT, Pantnagar \\
\hline $\mathbf{3 3}$ & PU 1617 & PM 5 x PU 31 & GBPAUT, Pantnagar \\
\hline $\mathbf{3 4}$ & PU 609-43 & TAU 1 x BDU-1 & MPKV, Jalagaon \\
\hline $\mathbf{3 5}$ & PU 1541 & PU 31 x TU 94-2 & GBPUA\&T, Pantnagar \\
\hline $\mathbf{3 6}$ & PU 1612 & PM 5 x PU 31 & GBPUA\&T, Pantnagar \\
\hline $\mathbf{3 7}$ & PUSA B 51 & $\begin{array}{l}\text { Mutant of Shekhar 2 (50 KR } \\
\text { gamma) }\end{array}$ & IARI, RS Pusa (Bihar) \\
\hline $\mathbf{3 8}$ & RU 03-22-4 & PDU 1 x TU 94-2 & IGKVV, Raipur \\
\hline $\mathbf{3 9}$ & RUB 14-09 & BU 1 x RUG 46 & BAU, Ranchi \\
\hline $\mathbf{4 0}$ & RUB 15-04 & PU -19 x IPU 2-43 & BAU, Ranchi \\
\hline $\mathbf{4 1}$ & SB 42-8 & T-9 x WBU 109 & Shillongani \\
\hline $\mathbf{4 2}$ & SBC 50 & SBC 40 x SBC 47 & RARA, Shillonani \\
\hline $\mathbf{4 3}$ & SKNU 1716 & Vamban 4 x NC 17556 & SDAU, S.K. Nagar \\
\hline $\mathbf{4 4}$ & TBG 129 & PU 31 x LBG 752 & RARS, Triputi \\
\hline $\mathbf{4 5}$ & TU 139 & TAU 1x IPU 2-43 & PDKV, Akola \\
\hline $\mathbf{4 6}$ & Uttara $($ Ch. $)$ & NP 19 x T 9 & IIPR. Kanpur \\
\hline $\mathbf{4 7}$ & VBG 12-110 & Mash 114 x Vamban 3 & NPRC, Vamban \\
\hline $\mathbf{4 8}$ & VBG 17-007 & VBN 5 x MDU 1 & NPRC, Vamban \\
\hline $\mathbf{4 9}$ & VBG 17-012 & VBN 4 x Uttara & NPRC, Vamban \\
\hline $\mathbf{5 0}$ & VBG 17-026 & KUG 365 x MDU 1 & NPRC, Vamban \\
\hline & & & \\
\hline
\end{tabular}

Table.2 Analysis of variance for 14 different characters in 50 genotypes of black gram

\begin{tabular}{|c|r|c|c|c|c|c|c|c|}
\hline $\begin{array}{c}\text { Source Of } \\
\text { Variation }\end{array}$ & $\begin{array}{c}\text { Degrees } \\
\text { Of } \\
\text { Freedom }\end{array}$ & $\mathbf{5 0 \%} \mathbf{F}$ & $\mathbf{D 2 M}$ & $\mathbf{P ~ H}$ & $\mathbf{1}^{\circ} \mathbf{B}$ & $\mathbf{2}^{\circ} \mathbf{B}$ & $\mathbf{S} / \mathbf{P D}$ & $\mathbf{S} / \mathbf{P}$ \\
\hline Replication & 2 & $104.66^{* *}$ & $78.00^{* *}$ & 13.04 & $5.36^{* *}$ & 0.4 & $1.96^{* *}$ & 1.8 \\
\hline Genotypes & 49 & $5.34^{*}$ & $18.51^{*}$ & $197.63^{* *}$ & $2.26^{* *}$ & $13.2^{* *}$ & $0.5^{* *}$ & $1243.11^{* *}$ \\
\hline Error & 98 & 3.43 & 12.38 & 5.97 & 0.37 & 0.55 & 0.16 & 58.65 \\
\hline C V & & 4.31 & 4.79 & 5.98 & 10.68 & 8.28 & 5.49 & 5.28 \\
\hline
\end{tabular}

\begin{tabular}{|c|r|c|c|c|c|c|c|c|}
\hline $\begin{array}{c}\text { Source Of } \\
\text { Variation }\end{array}$ & $\begin{array}{c}\text { Degrees Of } \\
\text { Freedom }\end{array}$ & POD L & C/P & POD/P & B Y/P & S Y/P & HI & $\begin{array}{c}100 \\
\text { SW }\end{array}$ \\
\hline Replication & 2 & $1.14^{* *}$ & 0.67 & $64.33^{* *}$ & $82.44^{* *}$ & 0.58 & $204.80^{* *}$ & $0.21^{*}$ \\
\hline Genotypes & 49 & $0.2^{* *}$ & $13.97^{* *}$ & $154.63^{* *}$ & $29.4^{*}$ & $3.28^{* *}$ & $105.23 * *$ & $0.29^{* *}$ \\
\hline Error & 98 & 0.08 & 0.71 & 9.65 & 2.15 & 0.54 & 21.16 & 0.06 \\
\hline C V & & 6.09 & 7.34 & 9.67 & 7.04 & 10.25 & 13.05 & 5.01 \\
\hline
\end{tabular}

** $1 \%$ Level of significance $* \mathbf{5 \%}$ Level of significance

$50 \%$ F- Days to $50 \%$ flowering, D2M- Days to maturity, PH- Plant Height, $1^{\circ}$ B- Number of primary branches per plant, $2^{\circ}$ B- Number of secondary branches per plant, S/Pd- Number of seeds per pod, S/P- Number of seeds per plant, Pod L- Pod length, C/S-Number of clusters per plant, Pod/P- Number of pods per plant, B Y/P- Biological yield per plant, SY/P- Seed yield per plant, HI-Harvest index, 100SW- 100 seed weight. 
Table.4 Genetic variability parameters for 14 different traits in 50 black gram genotypes

\begin{tabular}{|r|l|c|c|c|c|c|c|c|c|}
\hline $\begin{array}{l}\text { SL. } \\
\text { NO. }\end{array}$ & Characters & GCV & PCV & $\begin{array}{c}\text { Heritability } \\
\text { (BS) }\end{array}$ & $\begin{array}{c}\text { Genetic } \\
\text { Advance }\end{array}$ & $\begin{array}{c}\text { G. A. in } \\
\text { \% of } \\
\text { Mean }\end{array}$ & Minimum & Maximum & $\begin{array}{c}\text { Grand } \\
\text { Mean }\end{array}$ \\
\hline $\mathbf{1}$ & $50 \%$ F & 1.85 & 4.69 & 39.51 & 1.76 & 3.67 & 40.67 & 47.00 & 42.96 \\
\hline $\mathbf{2}$ & D2M & 1.94 & 5.17 & 37.63 & 1.76 & 2.20 & 69.33 & 80.33 & 73.41 \\
\hline $\mathbf{3}$ & PH & 19.58 & 20.48 & 95.63 & 8.91 & 22.18 & 26.48 & 62.33 & 40.82 \\
\hline $\mathbf{4}$ & $1^{\circ}$ B & 13.95 & 17.57 & 79.40 & 6.86 & 149.06 & 4.33 & 7.80 & 5.69 \\
\hline $\mathbf{5}$ & $2^{\circ}$ B & 22.84 & 24.30 & 94.02 & 9.55 & 93.60 & 6.20 & 14.40 & 9.00 \\
\hline $\mathbf{6}$ & S/Pd & 4.67 & 7.21 & 64.82 & 3.59 & 56.02 & 6.49 & 8.15 & 7.23 \\
\hline $\mathbf{7}$ & S/P & 13.69 & 14.67 & 93.31 & 7.36 & 6.88 & 96.00 & 193.67 & 145.11 \\
\hline $\mathbf{8}$ & POD L & 4.02 & 7.30 & 55.05 & 3.07 & 59.87 & 4.35 & 5.42 & 4.81 \\
\hline $\mathbf{9}$ & C/P & 18.31 & 19.73 & 92.81 & 8.49 & 70.77 & 7.87 & 17.47 & 11.49 \\
\hline $\mathbf{1 0}$ & Pd/P & 21.63 & 23.69 & 91.30 & 9.15 & 35.48 & 19.33 & 50.13 & 32.14 \\
\hline $\mathbf{1 1}$ & BY/P & 14.47 & 16.09 & 89.92 & 7.43 & 40.82 & 14.87 & 28.60 & 20.83 \\
\hline $\mathbf{1 2}$ & S Y/P & 13.30 & 16.79 & 79.21 & 6.69 & 141.96 & 4.71 & 9.71 & 7.19 \\
\hline $\mathbf{1 3}$ & HI & 15.03 & 19.91 & 75.48 & 6.94 & 35.35 & 21.91 & 50.73 & 35.22 \\
\hline $\mathbf{1 4}$ & 100 SW & 5.63 & 7.53 & 74.66 & 4.22 & 92.99 & 3.90 & 5.40 & 4.96 \\
\hline
\end{tabular}

$50 \%$ F- Days to $50 \%$ flowering, D2M- Days to maturity, PH- Plant Height, $1^{\circ} \mathrm{B}$ - Number of primary branches per plant, $2^{\circ} \mathrm{B}$ - Number of secondary branches per plant, S/Pd- Number of seeds per pod, S/P- Number of seeds per plant, Pod L- Pod length, C/S-Number of clusters per plant, Pod/P- Number of pods per plant, B Y/P- Biological yield per plant, SY/P- Seed yield per plant, HI-Harvest index, 100SW- 100 seed weight.

\section{References}

Anonymous. (2017-18). Pulses Revolution from Food to Nutrition, Directorate of Pulse Development, Dept. of Agri., Cooperation and Farmer Welfare. Ministry of Agriculture and Farmer Welfare, Govt. of India.

Burton, G.W. (1952). Quantitative inheritance in the interpretation of numerical plantation data. New Zealand J. Sci., 6: 39-59

Gupta, P., Semwal, B.D. and Gupta, D. (2006). Genetic variability, heritability and genetic advance for some traits in black gram (Vigna Mungo (L.) Hepper). Progress. Agric., 6(2): 164-166.

Johnson, H.W., Robinson, H.F. and Comstock, R.E. (1955). Estimates of genetic and environmental variability in soybean. Agron. J., 47: 314-318
Konda, C.R., Salimath, P.M. and Mishra, M.N. (2009). Genetic variability studies for productivity and its components in blackgram [Vigna munga (L.) Hepper]. Legume Res. Int. J., 32(1): 59-61.

Makeen, K., Abrahim, G., Jan, A. and Singh, A.K. (2007). Genetic variability and correlations studies on yield and its components in mungbean (Vigna radiata (L.) wilezek). J. of Agron., 6(1): 216.

Neelavathi, S. and Govindarasu, R. (2010). Analysis of variability and diversity in rice fallow blackgram [Vigna Mungo (L.) Hepper]. Legume Res. -An Int. J., 33(3): 206-210.

Panse, V.G. (1957). Genetics and Quantitative characters in relation to plant breeding. Ind. J. Genet., 17: 318-328.

Paterson, A.H., Tanksley SD., Sorrells, M.E. (1991). DNA markers in plant improvement. Adv. Agron. 46: 39-90. 
Poehlman, J.M. (1991). History, description, classification and origin. In: Poehlman JM (ed) The mungbean, West View, Boulder, pp 6-21.

Ramya, B., Nallathambi, G. and Ram, S.G. (2014). Genetic Variability, Heritability and Genetic advance in Induced Mutagenesis Blackgram (Vigna mungo (L). Hepper). Plant Arch., 14(1): 139141.

Reddy, D., Venkateswarlu, O., Jyothi, G.L. and Obaiah, M.C. (2011). Genetic parameters and inter-relationship analysis in blackgram [Vigna Mungo (L.) Hepper]. Legume Res. Int. J., 34(2): 149-152.

Venkatesan, N.M., Thangavel, P. and Ganesan, J. (2005). Genetic variability, heritability and genetic advance analysis in segregating generation of blackgram \{Vigna Mungo (L.)Hepper\}. Legume Res. Int. J., 28(1): 49-51.

\section{How to cite this article:}

Dondiba Kundagar, N. Brajendra Singh, M. Samuel Jeberson, Bireswar Sinha and Gopimohan Singh, N. 2021. Genetic Diversity Analysis in Black Gram (Vigna mungo L. Hepper). Int.J.Curr.Microbiol.App.Sci. 10(01): 1321-1328. doi: https://doi.org/10.20546/ijcmas.2021.1001.157 